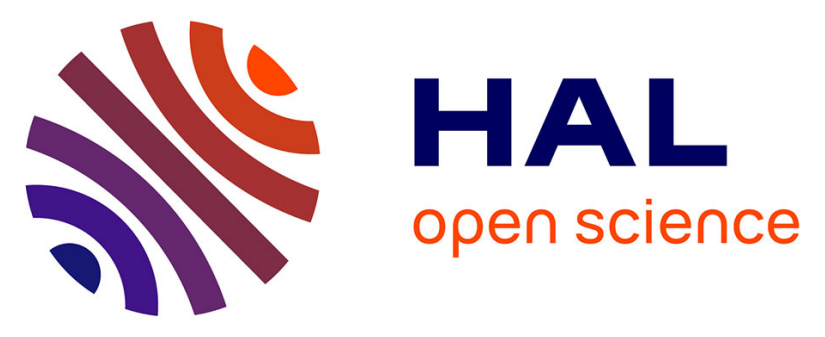

\title{
Optimization of the artificial neuronal network for the degradation and mineralization of amoxicillin photoinduced by the complex ferrioxalate with a gradual and progressive approach of the ligand
}

I.K. Benramdane, N. Nasrallah, A. Amrane, M. Kebir, M. Trari, F. Fourcade, A.A. Assadi, R. Maachi

\section{To cite this version:}

I.K. Benramdane, N. Nasrallah, A. Amrane, M. Kebir, M. Trari, et al.. Optimization of the artificial neuronal network for the degradation and mineralization of amoxicillin photoinduced by the complex ferrioxalate with a gradual and progressive approach of the ligand. Journal of Photochemistry and Photobiology A: Chemistry, 2021, 406, pp.112982. 10.1016/j.jphotochem.2020.112982 . hal03040579

\author{
HAL Id: hal-03040579 \\ https://hal.science/hal-03040579
}

Submitted on 15 Dec 2020

HAL is a multi-disciplinary open access archive for the deposit and dissemination of scientific research documents, whether they are published or not. The documents may come from teaching and research institutions in France or abroad, or from public or private research centers.
L'archive ouverte pluridisciplinaire HAL, est destinée au dépôt et à la diffusion de documents scientifiques de niveau recherche, publiés ou non, émanant des établissements d'enseignement et de recherche français ou étrangers, des laboratoires publics ou privés. 


\section{Optimization of the artificial neuronal network for the degradation and mineralization of amoxicillin photoinduced by the complex ferrioxalate with a gradual and progressive approach of the ligand}

Imene Kahina Benramdane ${ }^{\mathrm{a}, \mathrm{b}}$, Nourddine Nasrallah ${ }^{\mathrm{a}}$, Abdeltif Amrane ${ }^{\mathrm{b}}$, Mohammed Kebir ${ }^{\mathrm{a}, \mathrm{c}}$, Mohamed Trari ${ }^{\mathrm{d}}$, Florence Fourcade ${ }^{\mathrm{b}}$, Aymen Amine Assadi ${ }^{\mathrm{b}}$, Rachida Maachi ${ }^{\mathrm{a}}$.

a Laboratory of Reaction Engineering, Faculty of Mechanical Engineering and Process Engineering USTHB, BP 32, Algiers, Algeria.

b UMR CNRS 6226 'Sciences Chimiques de Rennes' (Université de Rennes 1/ENSCR) Equipe CIP, ENSCR, Avenue du Général Leclerc, 35700 Rennes, France.

${ }^{\mathbf{c}}$ Research Unit on Analysis and Technological Development in Environment (UR-ADTE/CRAPC), BP 384, BouIsmail Tipaza. Algeria.

${ }^{\mathrm{d}}$ Laboratory of Storage and Valorization of Renewable Energies Faculty of Chemistry USTHB, BP 32, Algiers, Algeria.

Graphical abstract 


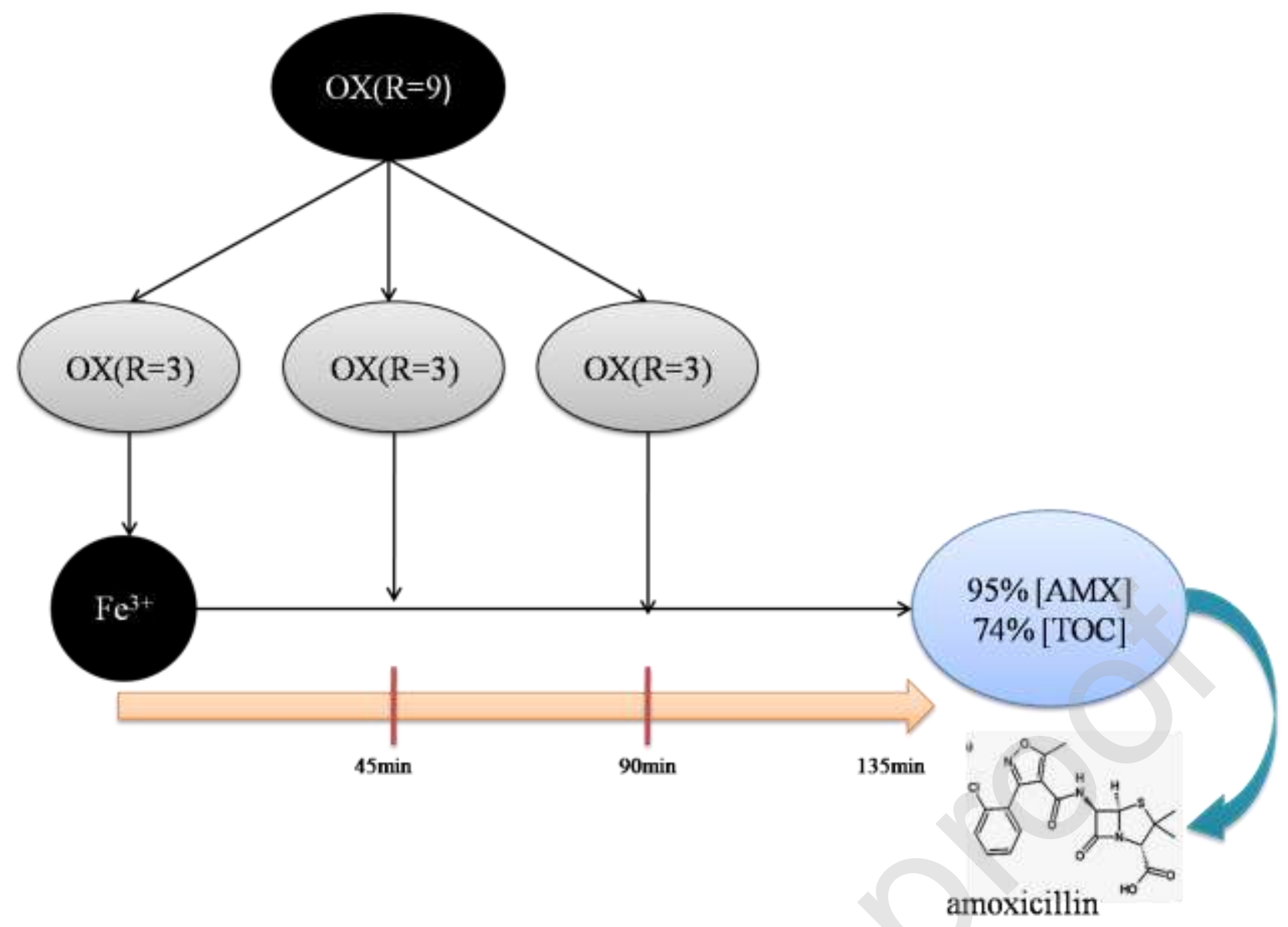

\section{Highlights}

- The use of the $\mathrm{Fe}^{3+}$-Oxalate complex under UV light was studied

- This study is done with an unadjusted $\mathrm{pH}$, with a result, in the end, of a pH final to neutrality.

- The using an approach progressive and gradual of the oxalate

- An artificial neural network optimized and modeled is used to simulate the degradation and mineralization of amoxicillin.

\section{Abstract}

In this work, the Ferrioxalate complex was used to mineralize the widely used antibiotic amoxicillin (AMX). The effect of operational parameters such as $\mathrm{Fe}^{3+}$ concentration, the molar ratio $\left(\mathrm{Oxalate} / \mathrm{Fe}^{3+}\right)$, and initial $\mathrm{pH}$ was studied for achieving high efficiency of degradation and mineralization. The effect of inorganic ions in the degradation of AMX was also investigated. Optimization of an Artificial Neural Network (ANN) to predict the performance of the process 
was realized. Neural networks were applied to model AMX degradation using 75 experimental data. Analysis of the results shows that the oxalate: iron ratio is limited to 3 with a $\mathrm{Fe}^{3+}$ concentration of $0.35 \mathrm{mM}$. In order to avoid this limitation, an alternative solution was adopted to increase the molar ratio with the gradual and progressive use of oxalic acid ligand. Almost total degradation and mineralization of AMX was achieved at the free initial $\mathrm{pH}$ of 2.8 and final $\mathrm{pH}$ of 6. The study of the effect of inorganic ions showed that bicarbonate and sulfate ions play an important role in contrast to $\mathrm{Cl}^{-}$ions with no noticeable influence. Neural network application resulted in a MSE of $1.1543 \times 10^{-5}$ and a correlation coefficient $r$ of 0.99 for AMX degradation and MSE of $1.12162 \times 10^{-5}$ with $r$ of 0.99 for mineralization. The model can describe successfully the percentage of degradation and mineralization of AMX under various conditions. ANN and NSGAII (Non-dominant Sorting Genetic Algorithm -II) hybrid method to solve a multi-objective problem was proposed to determine the optimal $\left(\mathrm{Fe}^{3+} / \mathrm{Ox} / \mathrm{UVA}\right)$ operating and process parameters. Keywords: Complex, Degradation, Mineralization, Artificial Neural Network, Injection method, Genetic algorithm.

\section{Introduction}

Pharmaceuticals are a class of health and care products widely used to promote human, animal, and plant health [1-3]. Among them, antibiotics are the most used drugs for the prevention or treatment of bacterial infections [3]. Antibiotics are subsequently discharged into various waters, mainly by municipalities and pharmaceutical laboratories. They are increasingly recognized as contaminants, bio-accumulative in the recipient environment (aquatic and terrestrial), and dangerous chemicals [4-5]. Effluents containing antibiotics must be treated chemically or physically to reduce the adverse effects of contaminated water [6-7]. Medicine comprises a wide range of various chemical structures (compounds of excreted metabolites) including AMX, which is a b-lactam antibiotic used as a broad-spectrum first-line anti-infectious treatment [8-10]. The study of AMX harmful environmental impact in aquatic environments is of utmost importance. 
The photo-Fenton process is an advanced oxidation process (AOP) generating hydroxyl radicals, when hydrogen peroxide reacts with an iron solute under UV radiation. The complex $\left[\mathrm{Fe}\left(\mathrm{H}_{2} \mathrm{O}\right)_{5} \mathrm{OH}\right]^{2+}$ hydroxo formed at $\mathrm{pH} \sim 3$ is photoactive generating $\mathrm{Fe}^{2+}$ ions [11-13].

The photo-Fenton process is very effective in the $\mathrm{pH}$ range $(2<\mathrm{pH}<4)$. The inefficiency of the process found at higher $\mathrm{pH}$ values is generally attributed to the precipitation of ferric oxyhydroxide [14].

$\mathrm{Fe}^{2+}$ ions can be better regenerated by the addition of chelates of organic acids such as carboxylates, hydroxyl-carboxylates of amino-polycarboxylates, and natural organic acids. These chelates coordinate with $\mathrm{Fe}^{3+}$, thus inducing a photochemical reduction of $\mathrm{Fe}^{3+}$ to $\mathrm{Fe}^{2+}$ via a ligand-to-metal charge-transfer (LMCT) to generate $\mathrm{Fe}^{2+}[15-17]$.

The photo-decomposition reaction (charge transfer from the ligand to the metal) of the $\mathrm{Fe}^{3+} /$ oxalate complexes is written as follows [17-18]:

$$
\begin{aligned}
& {\left[\mathrm{Fe}^{3+}\left(C_{2} O_{4}\right)_{3}\right]^{3-}+\mathrm{UV} \longrightarrow\left[\mathrm{Fe}^{2+}\left(C_{2} O_{4}\right)_{2}\right]^{3-}+\mathrm{C}_{2} \mathrm{O}_{4}^{\cdot-}} \\
& \mathrm{C}_{2} \mathrm{O}_{4}^{\cdot-}+\left[\mathrm{Fe}^{3+}\left(C_{2} O_{4}\right)_{3}\right]^{3-} \longrightarrow\left[\mathrm{Fe}^{2+}\left(C_{2} O_{4}\right)_{2}\right]^{3-}+\mathrm{C}_{2} \mathrm{O}_{4}^{\cdot-}+2 \\
& \mathrm{C}_{2} \mathrm{O}_{4}^{\circ-}+\mathrm{O}_{2} \longrightarrow 2 \mathrm{CO}_{2}+\mathrm{O}_{2}^{--}
\end{aligned}
$$

According to the above reactions, photolysis of the $\mathrm{Fe}^{3+}$ complex is followed by dissociation of the oxalate radical $\mathrm{C}_{2} \mathrm{O}_{4}^{--}$, the latter reacts with molecular oxygen to give $\mathrm{O}_{2}^{--}$or is in equilibrium with $\mathrm{HO}_{2}^{\cdot-}(\mathrm{pKa}=4.8)$. The disproportionation product of $\mathrm{HO}_{2}^{--} / \mathrm{O}_{2}^{--}$and $\mathrm{H}_{2} \mathrm{O}_{2}$ according to the following reactions [19]:

$$
\begin{aligned}
& 2 \mathrm{HO}_{2}^{-} \longrightarrow \mathrm{H}_{2} \mathrm{O}_{2}+\mathrm{O}_{2} \\
& \mathrm{Fe}^{2+}+\mathrm{HO}_{2}^{\cdot}+\mathrm{H}^{+} \longrightarrow \mathrm{Fe}^{3+}+\mathrm{H}_{2} \mathrm{O}_{2}
\end{aligned}
$$

The hydrogen peroxide formed from $\mathrm{HO}_{2}^{\circ-} / \mathrm{O}_{2}^{--}$reacts with $\mathrm{Fe}^{2+}$ giving rise to the Fenton reaction [18].

$\mathrm{Fe}^{2+}+\mathrm{H}_{2} \mathrm{O}_{2} \longrightarrow \mathrm{Fe}^{3+}+\mathrm{OH}^{\bullet}+\mathrm{OH}^{-}$

Besides, chelates increase the solubility of iron and allow the photo-Fenton process to operate in a wider $\mathrm{pH}$ range instead of a specific $\mathrm{pH}$ around 3 [20-21]. The significant effect of chelates on the degradation of organic pollutants has been attracting considerable attention over the last decades [22]. 
The lack of selectivity of ${ }^{\bullet} \mathrm{OH}$ radicals in AOP reaction mechanisms makes it difficult to use phenomenological kinetic models and simple description models [23]. Thus, an artificial neural network (ANN) has been used as an alternative tool for modeling complex industrial processes [24]. ANN is of great interest in chemical engineering, including the AOP study [25]. However, it must be trained with a relevant set of data to model the neural network and to address the inaccessible complexity to the phenomenology. Thus, it must adjust to generate responses from a set of entries [26]. ANN is a modern modeling tool consisting of input, output, and hidden layers whose outputs are sums of weighted inputs. It is a technique, which allows better treatment of quantitative variables with exceptional learning from experience and estimation of uncertain systems with reliable results [23-24]. In addition, finding optimal conditions of the operating parameters to achieve the best AMX degradation and mineralization with the $\left(\mathrm{Fe}^{3+/} \mathrm{Ox} / \mathrm{UVA}\right)$ process is a complex task. In this respect, a computer-based artificial intelligence technique, such as the genetic algorithm (GA), is a very helpful tool for solving nonlinear stochastic optimization problems [27].

The objective of this paper is to work with solutions at unadjusted (initial) $\mathrm{pH}$ to obtain a final $\mathrm{pH}$ close to 7 . A thorough investigation of the effect of influential parameters is undertaken as well as that of inorganic ions, with the aim of achieving degradation and mineralization of potential pharmaceutical pollutant Amoxicillin. For this purpose, several artificial neural network (ANN) models were developed to simulate the degradation and mineralization of AMX using the ferrioxalate complex under UVA light. The performance of the network was optimized by changing the network type, the training function, the adaptation learning function, and the transfer function for each input and output layer to obtain the best fit between the experimental and modeling data. Also, the non-dominated sorting genetic algorithm (NSGA-II) was employed to optimize AMX degradation and mineralization design.

\section{Materials and methods}

\subsection{Chemicals and reagents}

Analytical grade amoxicillin (AMX, $\left.\mathrm{C}_{16} \mathrm{H}_{19} \mathrm{~N}_{3} \mathrm{O}_{5} \mathrm{~S}\right), \mathrm{FeCl}_{3}$ (97\% purity), $\mathrm{Fe}\left(\mathrm{SO}_{4}\right)_{2} 6 \mathrm{H}_{2}$ (99\%), $\mathrm{H}_{2} \mathrm{O}_{2} 50 \%$ (w/v), $\mathrm{NaOH}(98 \%), \mathrm{Na}_{2} \mathrm{SO}_{4}(>99 \%), \mathrm{KSCN}(99 \%)$ were supplied by Sigma- 
Aldrich, $\mathrm{HCl}\left(37 \%\right.$ v/v), $\mathrm{NaHCO}_{3}(99 \%), \mathrm{NaCl}$ (99.5\%), by Across Organics, hydrated oxalic acid $\left(\mathrm{C}_{2} \mathrm{H}_{2} \mathrm{O}_{4}, 2 \mathrm{H}_{2} \mathrm{O}\right)$ by Merck. All solutions were prepared with high-purity water obtained from a Millipore Milli-Q system.

\subsection{Analysis method}

The experiments were performed in a double-walled photoreactor with a laboratory-scale cooling circuit equipped with a $24 \mathrm{~W} \mathrm{UV}_{\mathrm{A}}$ light simulator (Philips PL/L).

Typically, an AMX solution of $100 \mathrm{mg} / \mathrm{L}$ initial concentration with a known initial $\mathrm{pH}$ at room temperature was first introduced into the photoreactor. The solution was constantly stirred magnetically at $200 \mathrm{rpm}$ to ensure a good homogenization. Before irradiation, a volume of oxalic acid of known concentration was introduced to first acidify the reaction mixture and then the iron solution was added, the total reaction volume was kept at $900 \mathrm{~mL}$ throughout the experiments.

The residual concentration of AMX was analyzed by a Waters 996 Photodiode Array Detector HPLC system, which includes a Waters 600 LCD Pump. The column used type C-The mobile phase was a mixture of acetonitrile/ultrapure water $(05 / 95, \mathrm{v} / \mathrm{v})$ and $0.1 \%$ of formic acid with a flow rate of $1 \mathrm{~mL} / \mathrm{min}$ and a sample injection volume of $20 \mu \mathrm{L}$. The retention time was about 6 min with a wavelength of $228 \mathrm{~nm}$. Total organic carbon (TOC) analysis was carried out using a TOC-VCPH/CPG Shimadzu total organic analyzer. Since the use of oxalic acid as a ligand influences the TOC results, all manipulations were replicated with the same operating conditions but without AMX, a subtraction of the two results was presented in all results of the follow-up mineralization. A Thermo Scientific DIONEX DX120 ion chromatography system with a stationary phase consisting of an AS19 anion exchange column $(4 \times 250 \mathrm{~mm})$ and a mobile phase of $\mathrm{KOH}$ solution (12 M) was used for the determination of oxalic acid. A gradient elution mode was used for analysis. The flow rate was set at $1 \mathrm{~mL} / \mathrm{min}$ [27]. A retention time of $19 \mathrm{~min}$ was taken for oxalic acid. $\mathrm{Fe}^{3+}$ was analyzed performed by spectrophotometry; the technique is based on the use of a complexing agent between $\mathrm{Fe}^{3+}$ and $\mathrm{SCN}^{-}[26]$.

\section{Results and discussion}

\subsection{Effect of $\mathrm{Fe}^{3+}$}


Before starting this study, we carried out a comparison between the Photo-Fenton process $\left(\mathrm{Fe}^{2+} / \mathrm{H}_{2} \mathrm{O}_{2} / \mathrm{UV}\right)$ and the modified Photo-Fenton $\left(\mathrm{Fe}^{3+} / \mathrm{Ox} / \mathrm{UV}\right)$ process using an equal concentration of $0.05 \mathrm{mM}$ for $\mathrm{Fe}^{3+}, \mathrm{Fe}^{2+}, \mathrm{Ox}, \mathrm{H}_{2} \mathrm{O}_{2}$ and an AMX concentration of $100 \mathrm{mg} / \mathrm{L}$. According to (Fig. 1), a slight difference between the two processes can be observed, where the percent decrease in AMX is larger for the modified photo-Fenton process than the initial photoFenton process.

It can also be noted that the degradation kinetics of AMX is faster for the photo-Fenton process. This is a significant advantage as the production of hydroxide radicals is imminent for the photo Fenton process while for the modified photo-Fenton process, it takes longer to produce $\mathrm{H}_{2} \mathrm{O}_{2}$ in the solution (reaction.5). Then, reaction with $\mathrm{Fe}^{2+}$ to produce in turn hydroxide radicals via the reaction .6. Also, in this study, a variation of the concentration of $\mathrm{Fe}^{3+}$ keeping the molar ratio $\mathrm{R}=$ $\left(\mathrm{Ox} / \mathrm{Fe}^{3+}\right)$ constant was realized in the beginning. The best result was obtained for a concentration of $0.35 \mathrm{mM}$ (Fig.2). Beyond this value, the rate of degradation and mineralization decreased. Other results Fig S1were obtained for higher concentrations of $\mathrm{Fe}^{3+}$ up to $0.65 \mathrm{mM}$. According to this data, It has also been observed that the rates of degradation and mineralization decreasing with an increasing $\mathrm{Fe}^{3+}$ concentration beyond $0.35 \mathrm{mM}$.

This means that one of the reagents is problematic. And it is due to the increase in the concentration of oxalic acid, that it subsequently inhibits the mechanism.

The solution becomes more acidic at high oxalic acid concentration, which slows down the production of ${ }^{\bullet} \mathrm{OH}$ radicals, due to the non-complexation of $\mathrm{Fe}^{3+}$ with $\mathrm{C}_{2} \mathrm{O}_{4}{ }^{2-}($ Fig. 2 a and $\mathbf{b})$. Also, as shown in (Fig.2c and d) for $\mathrm{Fe}^{3+}$ concentrations less than $0.45 \mathrm{mM}, \mathrm{Fe}^{3+}$ and $\mathrm{C}_{2} \mathrm{O}_{4}{ }^{2-}$ are completely regenerated and consumed respectively, thus proving that complexation between the metal and ion occurs [27-28].

\subsection{Effect of molar ratio}

Since the Ferrioxalate complex reaches saturation with 3 moles of the oxalate $\mathrm{Fe}\left(\mathrm{C}_{2} \mathrm{O}_{4}\right)_{3}^{-3}$, an optimal molar ratio of 3 was used [29]. 
Beyond the molar ratio of 3, the increase in oxalic acid concentration led to the same problems already encountered in section 3.1. The diagram of the distribution of ferric hydroxyl species (Fig. 3) helps to clarify that with the present conditions and for an initial strong acidic pH value $(\mathrm{pH})$, complexation does not occur, thus limiting the amount of ligands.

For a ratio greater than 3 , there is an excess of oxalate, the time that $\mathrm{Fe}^{3+}$ regenerates, the oxalate ion acts as an organic compound and would therefore compete with AMX and the intermediates react with free radicals, thus reducing the degradation and mineralization process efficiency [29-30]. As shown in (Fig. 4), the target was not reached with a molar ratio of 3. The fact that a molar ratio of 3 is the maximum ratio to be used, requires the use of an alternative solution. Knowing that under favorable conditions, the final $\mathrm{pH}$ value increases and it is possible to use another approach to add, after the final $\mathrm{pH}$ stabilization, a similar and progressive amount of the ligand. The amount injected each time $(1.05 \mathrm{mM})$ is equivalent to a molar ratio of 3 for a gradual moment of $45 \mathrm{~min}$ until the desired quantity to inject is exhausted (Fig. 5c). This allowed us to reach a molar ratio of 9, where a total degradation and partial mineralization of AMX are observed in (Fig. 5a and b).

\subsection{Effect of pH}

Working with an unadjusted $\mathrm{pH}$ and having a neutral final $\mathrm{pH}$ close to 7 is one of the targeted objectives. $\mathrm{pH}$ is an important parameter in the POAs processes where $\mathrm{Fe}^{3+}$ is used as a catalyst because it affects and controls both the production rate of ${ }^{\bullet} \mathrm{OH}$ radicals and the nature of iron species in solution. The initial $\mathrm{pH}$ of the solution was adjusted by $\mathrm{HCl}(0.01 \mathrm{~N})$ and $\mathrm{NaOH}$ $(0.01 \mathrm{~N})$ solutions accordingly.

Several $\mathrm{pH}$ values were used (2, 4, 6 and 8), the unadjusted $\mathrm{pH}$ of 2.8. According to other studies, at high $\mathrm{pH}$ values, other ferric species are formed, leading to the total precipitation of $\mathrm{Fe}(\mathrm{OH})_{3(\mathrm{~s})}$ in its amorphous form [30], because of its low solubility product $\left(\mathrm{K}_{\mathrm{s}}=4 \times 10^{-38}\right)$. Below $\mathrm{pH}$ of 5 , other ferric ions such as $\mathrm{Fe}^{3+}, \mathrm{Fe}(\mathrm{OH})^{2+}, \mathrm{Fe}(\mathrm{OH})_{2}{ }^{2+}[31-32]$, exist in the aqueous solution.

It is noted that at too acidic a $\mathrm{pH}$, the degradation and mineralization of AMX decrease by 40 and $50 \%$ respectively, compared to initial results (Fig. 6.a). However, a high concentration of 
oxalate remains in the solution (Fig. 6. b) with an observed consumption yield of only $25 \%$ at $\mathrm{pH}$ 2.

At the small initial $\mathrm{pH}$, weak degradation and mineralization rates were observed with respective yields of 60 and $65 \%$, lower than the corresponding initial results. In addition, a significant amount of $\mathrm{H}_{2} \mathrm{C}_{2} \mathrm{O}_{4}$ remains in solution, with consumption efficiency not exceeding 20\%. The remaining $\mathrm{H}_{2} \mathrm{C}_{2} \mathrm{O}_{4}$ in solution at high $\mathrm{pH}$ is due to the conversion of $\mathrm{Fe}^{3+}$ to other ferric species, which do not form a complex with the ligand. Therefore, the most favorable $\mathrm{pH}$ is the initial unadjusted $\mathrm{pH}$ of 2.8 . The final $\mathrm{pH}$ of 6 will be measured.

\subsection{ANN modeling}

An Artificial Neural Network (ANN) simulates the operating principle of the human brain that manages a flow of information from a database. It is a powerful model for calculating and establishing the complexity of the input-output relationships of a system [30-32]. The artificial neuron receives digital input information from neurons upstream through their weighted connections (each connection has a numeric value: the weight) [33-36].

The first layer receives the input variables $\left(\mathrm{Xi}=\mathrm{Fe}^{3+}\right.$ and $\left.\mathrm{R}\left(\mathrm{Ox} / \mathrm{Fe}^{3+}\right)\right)$ through the input neurons (i), transforms them with the activation function on the input neuron, and sends them to the neurons of the first hidden layer (j). The hidden layer consists of the neurons processing that receives the S-weighted sum (Eq. 7) from the input layer, transforming them using the activation function and finally transferring them to the next layer [37]:

$S_{i j}=W_{0}+\left[\sum_{n}^{i} w_{i j} * X_{i}\right]$

where $n$ is the number of input elements, $\mathrm{X}_{\mathrm{i}}$ the value of the neuron output of the previous layer, $\mathrm{W}_{\mathrm{ij}}$ the weight value between neurons $i$ and $j$, and $\mathrm{W}_{\mathrm{o}}$ the added bias.

The production equation in a three-layer network ( $n$ neurons in the input layer, $m$ neurons in the hidden layer and $p$ neurons in the output layer) is as follows [38]:

$Y_{k}=f_{k}\left(\sum_{j=1}^{m} w_{j k} \times f_{i}\left(\sum_{i=1}^{n} x_{i} \times w_{i j}\right)\right)+w_{o}$ 
$\mathrm{Y}_{\mathrm{k}}$ is one of the system outputs, $\mathrm{f}_{\mathrm{k}}$ and $\mathrm{f}_{\mathrm{j}}$ are successively the activation functions of the neuron $k$ of the output layer and the neuron $j$ of the hidden layer; $\mathrm{W}_{\mathrm{jk}}$ and $\mathrm{W}_{\mathrm{ij}}$ are successively the weights between the same neuron and the $\mathrm{k}^{\text {th }}$ exit neuron and the weight between the $\mathrm{i}^{\text {th }}$ and $\mathrm{j}^{\text {th }}$ neurons.

Output 1 of the network relates to AMX degradation (concentration of AMX) while Output 2 relates to AMX mineralization (TOC concentration).

Two types of ANN have used the present work, Feed Forward Back Propagation and Cascade Forward Back Spread [39]. The former, related to the propagation artificial neural network model, consists of input, hidden and output layers. The backpropagation learning algorithm was used to train these networks [40]. The cascade forward back propagation model is similar to the former network, but includes a weight transfer from the input to each layer and from each layer to successive ones [40-41].

\section{Trainlm (Levenberg-Marquard BP), Trainscg (Scaled conjugate gradient BP) training} algorithms, Learngd (Gradient descent weight/bias learning) and Learngdm (Gradient descent with momentum weight bias learning) learning functions were used in this work. For the hidden layer, two transfer functions were used, Tansig (Hyperbolic tangent sigmoid) and Logsig (Log sigmoid) and for the output layer, the transfer function is perlin and logsin making a total application of 32 models with different algorithms and functions. For all models, the number of neurons of the hidden layer was 10 to achieve the best simulation [35]. (Fig. 7) groups all the models. MATLAB software (version 2015a) was used to execute these operations.

The performance of the Feed Forward Back Propagation and Cascade Forward Back Propagation was evaluated using the mean squared error (MSE) and / or correlation coefficient (r) [42-44].

$\operatorname{MSE}=\frac{1}{\mathrm{Q}} \sum_{\mathrm{i}=1}^{\mathrm{i}=\mathrm{Q}}\left(\mathrm{y}_{\mathrm{i}, \text { pred }}-\mathrm{y}_{\mathrm{i}, \mathrm{exp}}\right)^{2}$

$r=\sqrt{1-\frac{\sum_{i=1}^{i=Q}\left(y_{p, i}-y_{e x p, i}\right)^{2}}{\sum_{i=1}^{i=Q}\left(y_{p, i}-y_{m}\right)^{2}}}$ 
Where $\mathrm{Q}$ is the number of data points, $\mathrm{y}_{\mathrm{p}, \mathrm{I}}$, the network prediction, yexp,i, the experimental response, $\mathrm{ym}$, the mean of the experimental value and $I$, a data index.

Table 1 shows the MSE objective for the rest of the work. After optimization, a neuron number ranging from1 to 8 was chosen.

As shown in Table.2, a neuron number of 2 in the hidden layer was chosen based on the low MSE value $\left(1.1534 \times 10^{-5}\right)$, the high $r$-value $(0.99)$ for degradation and to the corresponding values of $1.1216 \times 10^{-5}$ with r 0.99 regarding the mineralization. (Fig.8) represents the optimal neural network scheme used.

(Fig.9) shows a comparison between the experimental results with those calculated via neural network modeling. A correlation coefficient of 0.99 for both outputs was obtained; which confirms the fitting of the model to the experimental results and the successful results reproduction by the adjusted model.

\subsection{Genetic Algorithm}

Genetic algorithms (GA) are stochastic optimization algorithms based on the mechanisms of natural selection and genetics. They were originally developed by John Holland (1975) [45-46]. Any genetic algorithm with a common structure operates in the same way and follows the same methodology. First, a set of solutions or individuals is generated to train the initial population. Subsequently, individuals in the population are assessed and classified into the population. Then, a subset of parents is created to favor the best solutions and from this set, a group of children is generated by reproduction mechanisms (crossover and mutation). After creating the set of children, their performance is evaluated in order to compare their level of performance with the rest of the population and thus guide the construction of the new generation. Then, the process is repeated from this new generation until the stop criterion defined at the start is reached [47-49].

The NSGA-II proposed by Deb et al. [50] is a fast and elitist version of the genetic unordered sorting algorithm, which is an evolutionary approach to find an optimal solutions to complex multi-criteria optimization problems [51-52]. 
In this study, the degradation and mineralization of AMX were taken as objective functions. Decision variables include the two process parameters, the concentration of $\mathrm{Fe}^{3+}$ and Oxalate. The computer codes for the optimization of genetic algorithms were developed using MATLAB whose parameter values are given in Table. 3 below. The ANN model formed was integrated into the NSGA-II algorithm in serving as an objective function.

The purpose of applying NSGAII is to optimize the proposed treatment process involving the $\left(\mathrm{Fe}^{3+} /\right.$ Oxalate) complex under UVA light was to maximize the degradation and mineralization of AMX. The results of optimization using GA have shown that the best results were obtained when $\mathrm{Fe}^{3+}$ concentration is $0.39 \mathrm{mM}$ and molar ratio $\left(\mathrm{Ox} / \mathrm{Fe}^{3+}\right)$ ranges from 9.4 to 10.2 . The results are grouped in Table.4.

Finally, the performance of the $\left(\mathrm{Fe}^{3+} / \mathrm{Ox} / \mathrm{UVA}\right)$ process under the optimal conditions predicted by GA analysis was tested experimentally. Degradation and mineralization values were found to be in good agreement between the predicted values. The ANN coupled with AG (NSGAII) proved the robustness of the proposed model to degrade and mineralize the AMX.

\subsection{Effects of the solution matrix on AMX degradation}

In this section, different concentrations of some inorganic salts $\left(\mathrm{NaCl}, \mathrm{Na}_{2} \mathrm{SO}_{4}\right.$ and $\mathrm{NaHCO}_{3}$ ) were added to the system to evaluate their effect on AMX removal. The operating conditions were a $\mathrm{Fe}^{3+}$ concentration of $0.35 \mathrm{mM}$ and a molar ratio of 9.

From (Fig.10), it can be observed that and $\mathrm{SO}_{4}^{2-}$ ions influence significantly the progress of the reaction, by increasing their concentration, AMX degradation decreased from $31 \%$ and $12 \%$ for $\mathrm{SO}_{4}^{2-}$ and $\mathrm{HCO}_{3}^{-}$respectively for $100 \mathrm{mg} / \mathrm{L}$ concentration of $\mathrm{AMX}$. However, for $\mathrm{Cl}^{-}$ion, no decrease was noticed.

AMX degradation was considerably reduced with the addition of bicarbonate $\mathrm{HCO}_{3}^{-}$ions. Two mechanisms might be involved: either the bicarbonate and sulfate ions play the role of an inhibitor for ${ }^{\bullet} \mathrm{OH}$ radicals or they are complexed with $\mathrm{Fe}^{3+}$ (next reaction) [53-55]

$\mathrm{HO}^{\bullet}+\mathrm{HCO}_{3}^{-} \longrightarrow \mathrm{CO}_{3}^{\bullet-}+\mathrm{H}_{2} \mathrm{O}$ 


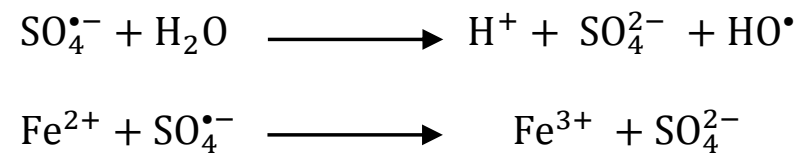

The addition of $\mathrm{Cl}^{-}$up to $100 \mathrm{mM}$ tends generally to affect the reaction mechanism. In such cases, generally, when $\mathrm{Cl}^{-}$is added to the solution, it acts as a scavenger by trapping the hydroxyl radicals as follows:

$$
\cdot \mathrm{OH}+\mathrm{Cl}^{-} \longrightarrow \quad \mathrm{ClOH} \quad\left(\mathrm{K}=4.3 \times 10^{9} \mathrm{M}^{-1} \mathrm{~s}^{-1}\right)
$$

The lack of inhibition by $\mathrm{Cl}^{-}$ions was observed for the AMX oxidation, the reaction of free radicals with AMX is faster than that of $\mathrm{Cl}^{-}$. The reaction rate of $\mathrm{AMX}$ with ${ }^{\circ} \mathrm{OH}$ is $10^{10} \mathrm{M}^{-1} \mathrm{~S}^{-1}$ while that of $\mathrm{Cl}^{-}$with ${ }^{\bullet} \mathrm{OH}$ is $4.3 \times 10^{9} \mathrm{M}^{-1} \mathrm{~S}^{-1}$. [56-57]

\section{Conclusion}

The $\mathrm{Fe}^{3+} /$ oxalate complex under UVA light was used to degrade and mineralize the antibiotic amoxicillin. The study of the operating parameters effect showed that the best AMX degradation and mineralization conditions were obtained for an unadjusted $\mathrm{pH}$ of 2.8 , a $\mathrm{Fe}^{3+}$ concentration of $0.35 \mathrm{mM}$ and a molar ratio of 9 with a gradual and progressive introduction of the ligand and a final $\mathrm{pH}$ of 6 . Bicarbonate and sulfate ions were found to have an inhibitory effect on the mechanism as the conversion yields decreased down to 31 and $12 \%$, respectively. However, no yield decrease was observed with $\mathrm{Cl}^{-}$ions. The cascade-type neural network, the Trainl training function and the learning function Learngdm were successfully used for the optimization. The transfer function for the hidden layer used was Logsing while for the output layer Perline was used with a MSE of $1.1957 \times 10^{-5}$ for degradation and $1.1948 \times 10^{-5}$ for mineralization. However, an optimization of the hidden layer neuron was carried out for the optimized model. The results showed that the best MSE and correlation coefficient were obtained for a number of neurons of 2 with a MSE of $1.1534 \times 10^{-5}$ and a correlation coefficient of 0.99 for the degradation. For 
mineralization, the respective values were $1.12162 \times 10^{-5}$ and 0.99 . This confirms that the adjusted model can reproduce the results of process with great accuracy. A multi-objective optimization model was also proposed to determine the optimal experimental parameters, where the efficiency of degradation and mineralization of AMX were taken as an objectives. The problem was resolved successfully using the NSGA-II algorithm to obtain the optimal conditions for the ( $\left.\mathrm{Fe}^{3+} / \mathrm{Ox} / \mathrm{UVA}\right)$ system under customized conditions.

\section{Author Statement}

- Imene Kahina Benramdane : Conceptualization- Methodology - Software -Data curation- (Writing - original draft).

- Nourddine Nasrallah: Supervision- Visualization.

- Abdeltif Amrane : Project administration

- Mohammed Kebir: Investigation- Formal analysis- Visualization- review and editing.

- Mohamed Trari : Review and editing.

- Florence Fourcade : Supervision.

- Aymen Amine Assadi : Supervision.

- Rachida Maachi : Project administration - Visualization.

\section{Note :}

The present work has not been published before in any form whatsoever, that it is not envisaged to publish it elsewhere. 


\section{References}

[1] B. Petrie, R. Barden, B. Kasprzyk-Hordern, A review on emerging contaminants in wastewaters and the environment: Current knowledge, understudied areas and recommendations for future monitoring, Water Research. 72 (2015) 3-27. https://doi.org/10.1016/j.watres.2014.08.053.

[2] J.L. Martinez, Environmental pollution by antibiotics and by antibiotic resistance determinants, Environmental Pollution. 157 (2009) 2893-2902. https://doi.org/10.1016/j.envpol.2009.05.051.

[3] G. Moussavi, A. Alahabadi, K. Yaghmaeian, M. Eskandari, Preparation, characterization and adsorption potential of the $\mathrm{NH} 4 \mathrm{Cl}$-induced activated carbon for the removal of amoxicillin antibiotic from water, Chemical Engineering Journal. 217 (2013) 119-128. https://doi.org/10.1016/j.cej.2012.11.069.

[4] P. Verlicchi, M. Al Aukidy, E. Zambello, What have we learned from worldwide experiences on the management and treatment of hospital effluent? - An overview and a discussion on perspectives, Science of The Total Environment. 514 (2015) 467-491. https://doi.org/10.1016/j.scitotenv.2015.02.020.

[5] S. Harris, C. Morris, D. Morris, M. Cormican, E. Cummins, Antimicrobial resistant Escherichia coli in the municipal wastewater system: Effect of hospital effluent and environmental fate, Science of The Total Environment. 468-469 (2014) 1078-1085. https://doi.org/10.1016/j.scitotenv.2013.09.017.

[6] E.S. Elmolla, M. Chaudhuri, Degradation of the antibiotics amoxicillin, ampicillin and cloxacillin in aqueous solution by the photo-Fenton process, Journal of Hazardous Materials. 172 (2009) 14761481. https://doi.org/10.1016/j.jhazmat.2009.08.015.

[7] O.B. Ayodele, Effect of phosphoric acid treatment on kaolinite supported ferrioxalate catalyst for the degradation of amoxicillin in batch photo-Fenton process, Applied Clay Science. 72 (2013) 7483. https://doi.org/10.1016/j.clay.2013.01.004.

[8] F.S. Souza, V.V. da Silva, C.K. Rosin, L. Hainzenreder, A. Arenzon, L.A. Féris, Comparison of different advanced oxidation processes for the removal of amoxicillin in aqueous solution, Environmental Technology. 39 (2018) 549-557. https://doi.org/10.1080/09593330.2017.1306116.

[9] I. Gozlan, A. Rotstein, D. Avisar, Amoxicillin-degradation products formed under controlled environmental conditions: Identification and determination in the aquatic environment, Chemosphere. 91 (2013) 985-992. https://doi.org/10.1016/j.chemosphere.2013.01.095.

[10] D. Dimitrakopoulou, I. Rethemiotaki, Z. Frontistis, N.P. Xekoukoulotakis, D. Venieri, D. Mantzavinos, Degradation, mineralization and antibiotic inactivation of amoxicillin by UV-A/TiO2 photocatalysis, Journal of Environmental Management. 98 (2012) 168-174. https://doi.org/10.1016/j.jenvman.2012.01.010.

[11] B. Garza-Campos, D. Morales-Acosta, A. Hernández-Ramírez, J.L. Guzmán-Mar, L. Hinojosa-Reyes, J. Manríquez, E.J. Ruiz-Ruiz, Air diffusion electrodes based on synthetized mesoporous carbon for application in amoxicillin degradation by electro-Fenton and solar photo electro-Fenton, Electrochimica Acta. 269 (2018) 232-240. https://doi.org/10.1016/j.electacta.2018.02.139.

[12] E. Brillas, I. Sirés, M.A. Oturan, Electro-Fenton Process and Related Electrochemical Technologies Based on Fenton's Reaction Chemistry, Chemical Reviews. 109 (2009) 6570-6631. https://doi.org/10.1021/cr900136g.

[13] J. Ramírez, L.A. Godínez, M. Méndez, Y. Meas, F.J. Rodríguez, Heterogeneous photo-electro-Fenton process using different iron supporting materials, Journal of Applied Electrochemistry. 40 (2010) 1729-1736. https://doi.org/10.1007/s10800-010-0157-z.

[14] M. Chaudhuri, M.Z.B.A. Wahap, A.C. Affam, Treatment of aqueous solution of antibiotics amoxicillin and cloxacillin by modified photo-Fenton process, Desalination and Water Treatment. 51 (2013) 7255-7268. https://doi.org/10.1080/19443994.2013.773565.

[15] L.I. Doumic, P.A. Soares, M.A. Ayude, M. Cassanello, R.A.R. Boaventura, V.J.P. Vilar, Enhancement of a solar photo-Fenton reaction by using ferrioxalate complexes for the treatment of a synthetic cotton-textile dyeing wastewater, Chemical Engineering Journal. 277 (2015) 86-96. https://doi.org/10.1016/j.cej.2015.04.074. 
[16] D. Xiao, Y. Guo, X. Lou, C. Fang, Z. Wang, J. Liu, Distinct effects of oxalate versus malonate on the iron redox chemistry: Implications for the photo-Fenton reaction, Chemosphere. 103 (2014) 354358. https://doi.org/10.1016/j.chemosphere.2013.11.069.

[17] H. Cui, X. Gu, S. Lu, X. Fu, X. Zhang, G.Y. Fu, Z. Qiu, Q. Sui, Degradation of ethylbenzene in aqueous solution by sodium percarbonate activated with EDDS-Fe(III) complex, Chemical Engineering Journal. 309 (2017) 80-88. https://doi.org/10.1016/j.cej.2016.10.029.

[18] S. Chergui, Procédé d'oxydation avancée pour le traitement des eaux usées: Principe et applications, (n.d.) 8.

[19] G. Liu, S. Zheng, X. Xing, Y. Li, D. Yin, Y. Ding, W. Pang, Fe(III)-oxalate complexes mediated photolysis of aqueous alkylphenol ethoxylates under simulated sunlight conditions, Chemosphere. 78 (2010) 402-408. https://doi.org/10.1016/j.chemosphere.2009.11.002.

[20] A. De Luca, R.F. Dantas, S. Esplugas, Assessment of iron chelates efficiency for photo-Fenton at neutral pH, Water Research. 61 (2014) 232-242. https://doi.org/10.1016/j.watres.2014.05.033.

[21] Y. Zhang, M. Zhou, A critical review of the application of chelating agents to enable Fenton and Fenton-like reactions at high pH values, Journal of Hazardous Materials. 362 (2018) 436-450. https://doi.org/10.1016/j.jhazmat.2018.09.035.

[22] C. Ruales-Lonfat, J.F. Barona, A. Sienkiewicz, J. Vélez, L.N. Benítez, C. Pulgarín, Bacterial inactivation with iron citrate complex: A new source of dissolved iron in solar photo-Fenton process at nearneutral and alkaline pH, Applied Catalysis B: Environmental. 180 (2016) 379-390. https://doi.org/10.1016/j.apcatb.2015.06.030.

[23] Y. Brandão, J. Teodosio, F. Dias, W. Eustáquio, M. Benachour, Treatment of phenolic effluents by a thermochemical oxidation process (DiCTT) and modelling by artificial neural networks, Fuel. 110 (2013) 185-195. https://doi.org/10.1016/j.fuel.2012.12.046.

[24] W. Xiao, G. Nazario, H. Wu, H. Zhang, F. Cheng, A neural network based computational model to predict the output power of different types of photovoltaic cells, PLOS ONE. 12 (2017) e0184561. https://doi.org/10.1371/journal.pone.0184561.

[25] F. Ghanbary, N. Modirshahla, M. Khosravi, M.A. Behnajady, Synthesis of TiO2 nanoparticles in different thermal conditions and modeling its photocatalytic activity with artificial neural network, Journal of Environmental Sciences. 24 (2012) 750-756. https://doi.org/10.1016/S10010742(11)60815-2.

[26] M. Khayet, C. Cojocaru, Artificial neural network modeling and optimization of desalination by air gap membrane distillation, Separation and Purification Technology. 86 (2012) 171-182. https://doi.org/10.1016/j.seppur.2011.11.001.

[27] A. Hassani, A. Khataee, M. Fathinia, S. Karaca, Photocatalytic ozonation of ciprofloxacin from aqueous solution using TiO 2 /MMT nanocomposite: Nonlinear modeling and optimization of the process via artificial neural network integrated genetic algorithm, Process Safety and Environmental Protection. 116 (2018) 365-376. https://doi.org/10.1016/j.psep.2018.03.013.

[28] M. Haddou, Dégradation de dérivés de l'acide benzoïque par les procédés d'oxydation avancée en phase homogène et hétérogène : procédés Fenton, photo-Fenton et photocatalyse, Université de toulouse, 2010.

[29] Davididou et al. - 2017 - Degradation and mineralization of antipyrine by UV.pdf, (n.d.).

[30] G.D. Garson, Interpreting neural-network connection weights, Al Expert. (1991) 46-51.

[31] J.H.O.S. Pereira, D.B. Queirós, A.C. Reis, O.C. Nunes, M.T. Borges, R.A.R. Boaventura, V.J.P. Vilar, Process enhancement at near neutral $\mathrm{pH}$ of a homogeneous photo-Fenton reaction using ferricarboxylate complexes: Application to oxytetracycline degradation, Chemical Engineering Journal. 253 (2014) 217-228. https://doi.org/10.1016/j.cej.2014.05.037.

[32] J.J. Pignatello, E. Oliveros, A. MacKay, Advanced Oxidation Processes for Organic Contaminant Destruction Based on the Fenton Reaction and Related Chemistry, Critical Reviews in Environmental Science and Technology. 36 (2006) 1-84. https://doi.org/10.1080/10643380500326564.

[33] W. Cao, X. Wang, Z. Ming, J. Gao, A review on neural networks with random weights, Neurocomputing. 275 (2018) 278-287. https://doi.org/10.1016/j.neucom.2017.08.040.

[34] D. Salari, A. Niaei, A. Khataee, M. Zarei, Electrochemical treatment of dye solution containing C.I. Basic Yellow 2 by the peroxi-coagulation method and modeling of experimental results by artificial neural networks, Journal of Electroanalytical Chemistry. 629 (2009) 117-125. https://doi.org/10.1016/j.jelechem.2009.02.002.

[35] D.B. Jani, M. Mishra, P.K. Sahoo, Application of artificial neural network for predicting performance of solid desiccant cooling systems - A review, Renewable and Sustainable Energy Reviews. 80 (2017) 352-366. https://doi.org/10.1016/j.rser.2017.05.169. 
[36] M.Y. Diab, M.B. Beckers, Ouissem KHARROUBI Prévision des crues par modèle de réseau de neurones artificiels : application au bassin versant de l'Eure, (2013) 211.

[37] R. Tariq, Make your own neural network, 2016.

[38] S. Riad, Typologie et analyse hydrologique des eaux superficielles à partir de quelques bassins versants représentatifs du Maroc. Thèse de doctorat., Université des sciences et de technologies de Lille, 2003.

[39] M. Abbasi, A.R. Soleymani, J.B. Parsa, Degradation of Rhodamine B by an electrochemical ozone generating system consist of a Ti anode coated with nanocomposite of $\mathrm{Sn}-\mathrm{Sb}-\mathrm{Ni}$ oxide, Process Safety and Environmental Protection. 94 (2015) 140-148. https://doi.org/10.1016/j.psep.2015.01.007.

[40] H. Demuth, M. Beale, M. Hagan, Neural Network Toolbox, User"s Guide". The MathWorks, Inc., Natrick, USA. (2009).

[41] D.S. Badde, Cascade and Feed Forward Back propagation Artificial Neural Network Models for Prediction of Compressive Strength of Ready Mix Concrete, (n.d.) 6.

[42] Y. Mahdi, L. Mouhi, N. Guemras, K. Daoud, Coupling the image analysis and the artificial neural networks to predict a mixing time of a pharmaceutical powder, Journal of Fundamental and Applied Sciences. 8 (2018) 655. https://doi.org/10.4314/jfas.v8i3.1.

[43] A.R. Khataee, M.B. Kasiri, Artificial neural networks modeling of contaminated water treatment processes by homogeneous and heterogeneous nanocatalysis, Journal of Molecular Catalysis A: Chemical. 331 (2010) 86-100. https://doi.org/10.1016/j.molcata.2010.07.016.

[44] F. Nabizadeh Chianeh, J. Basiri Parsa, H. Rezaei Vahidian, Artificial neural network modeling for removal of azo dye from aqueous solutions by $\mathrm{Ti}$ anode coated with multiwall carbon nanotubes, Environmental Progress \& Sustainable Energy. 36 (2017) 1778-1784. https://doi.org/10.1002/ep.12650.

[45] Lehouche et al. - Application des Algorithmes génétiques à la comman.pdf, (n.d.).

[46] A.R. Khataee, M. Fathinia, M. Zarei, B. Izadkhah, S.W. Joo, Modeling and optimization of photocatalytic/photoassisted-electro-Fenton like degradation of phenol using a neural network coupled with genetic algorithm, Journal of Industrial and Engineering Chemistry. 20 (2014) 18521860. https://doi.org/10.1016/j.jiec.2013.08.042.

[47] G.D. Suditu, M. Secula, C.G. Piuleac, S. Curteanu, I. Poulios, Genetic Algorithms and Neural Networks Based Optimization Applied to the Wastewater Decolorization by Photocatalytic Reaction, Rev. Chim. 59 (2008). https://doi.org/10.37358/RC.08.7.1901.

[48] Yan et al. - 2019 - Modeling of solid oxide fuel cell (SOFC) electrode.pdf, (n.d.).

[49] Liu et al. - 2020 - Optimizing an ANN model with genetic algorithm (GA.pdf, (n.d.).

[50] K. Deb, An introduction to genetic algorithms, (n.d.) 23.

[51] I. Belaidi, K. Mohammedi, B. Brachemi, Mise en œuvre de l'Algorithme NSGAll pour l'Optimisation Multi-Objectif des paramètres de coupe en Fraisage en bout, (2009) 6.

[52] M.A. Sahali, I. Belaidi, R. Serra, Efficient genetic algorithm for multi-objective robust optimization of machining parameters with taking into account uncertainties, Int J Adv Manuf Technol. 77 (2015) 677-688. https://doi.org/10.1007/s00170-014-6441-z.

[53] G. Subramanian, G. Madras, Introducing saccharic acid as an efficient iron chelate to enhance photoFenton degradation of organic contaminants, Water Research. 104 (2016) 168-177. https://doi.org/10.1016/j.watres.2016.07.070.

[54] X. Fu, X. Gu, S. Lu, Z. Miao, M. Xu, X. Zhang, Z. Qiu, Q. Sui, Benzene depletion by Fe2+-catalyzed sodium percarbonate in aqueous solution, Chemical Engineering Journal. 267 (2015) 25-33. https://doi.org/10.1016/j.cej.2014.12.104.

[55] Devi et al. - 2013 - Effect of chloride and sulfate ions on the advance.pdf, (n.d.).

[56] X. Gu, Y. Wang, Z. Miao, S. Lu, Z. Qiu, Q. Sui, X. Guo, Degradation of trichloroethylene in aqueous solution by persulfate activated with Fe(III)-EDDS complex, Research on Chemical Intermediates. 43 (2017) 1-13. https://doi.org/10.1007/s11164-016-2601-0.

[57] V.A. Nadtochenko, J. Kiwi, Photolysis of $\mathrm{FeOH}^{2+}$ and $\mathrm{FeCl}^{2+}$ in Aqueous Solution. Photodissociation Kinetics and Quantum Yields, Inorganic Chemistry. 37 (1998) 5233-5238.

https://doi.org/10.1021/ic9804723. 


\section{Figure caption}

Fig.1 Comparison between the Photo Fenton process, - $-\left(\mathrm{Fe}^{2+} / \mathrm{H}_{2} \mathrm{O}_{2} / \mathrm{UVA}\right)$ and the modified Photo Fenton $\bullet-\left(\mathrm{Fe}^{3+} / \mathrm{oxalate} / \mathrm{UVA}\right)$. Parameters: $[\mathrm{AMX}]_{\mathrm{o}}=100 \mathrm{mg} \cdot \mathrm{L}^{-1},\left[\mathrm{Fe}^{3+}\right]_{\mathrm{o}}=\left[\mathrm{Fe}^{2+}\right]_{\mathrm{o}}=[\mathrm{Ox}]_{\mathrm{o}}$ $=\left[\mathrm{H}_{2} \mathrm{O}_{2}\right]_{\mathrm{o}}=0.05 \mathrm{mM}$ and $\mathrm{pHi}=3$, mixed for $45 \mathrm{~min}$.

Fig.2 Effect of the initial concentration of $\mathrm{Fe}^{3+},(\bullet-0.15 \mathrm{mM} ; \bullet-0.25 \mathrm{mM}$; $-0.35 \mathrm{mM}$; $0.45 \mathrm{mM}$ ) on the degradation and mineralization of AMX,: (a). Degradation yields of AMX;(b). Mineralization yields of AMX; (c).Consumption yields of oxalic acid; (d). $\mathrm{Fe}^{3+}$ oxidation yields. Process parameters: $[\mathrm{AMX}]_{\mathrm{o}}=100 \mathrm{mg} \cdot \mathrm{L}^{-1}, \mathrm{R}=1$ and initial $\mathrm{pH}$ unadjusted, mixed for $45 \mathrm{~min}$.

Fig.3 distribution diagram of ferric hydroxyl species as a function of $\mathrm{pH}$ for a solution containing $0.35 \mathrm{mM} \mathrm{Fe}^{3+}$ and $0.35 \mathrm{mM}$ oxalate. The distribution diagram was obtained by VISUAL MINTEQ Software.

Fig.4 Effect of the molar ratio, $(\bullet-\mathrm{R}=1 ; \bullet-\mathrm{R}=2 ; \bullet-\mathrm{R}=3)$ on the degradation and mineralization of AMX, (a). Degradation yields of AMX; (b).Mineralization yields of AMX; (c).Consumption yields of oxalic acid; (d). $\mathrm{Fe}^{3+}$ oxidation yields. Process parameters: $[\mathrm{AMX}]_{\mathrm{o}}=$ $100 \mathrm{mg} . \mathrm{L}^{-1},\left[\mathrm{Fe}^{3+}\right]_{\mathrm{o}}=0.35 \mathrm{mM}$ and initial $\mathrm{pH}$ unadjusted, mixed for $45 \mathrm{~min}$.

Fig.5 Influence of the molar ratio with an increase of oxalic acid by an injection method. (a). Degradation yields of AMX; (b) .Mineralization yields of AMX; (c).Consumption yields of oxalic acid; Process parameters: $[\mathrm{AMX}]_{\mathrm{o}}=100 \mathrm{mg} \cdot \mathrm{L}^{-1},\left[\mathrm{Fe}^{3+}\right]_{\mathrm{o}}=0.35 \mathrm{mM},[\mathrm{OX}]_{\mathrm{o}}=3.15 \mathrm{mM}(1.05$ $\mathrm{mM} * 3)$ and initial $\mathrm{pH}$ unadjusted, mixed for $135 \min (45 \mathrm{~min} * 3)$.

Fig.6 Effect of initial $\mathrm{pH}$ on the degradation and mineralization of AMX, (a). $\square$-Degradation yields of AMX, $\square$-Mineralization yields of AMX and $\bullet-\mathrm{pH}$ final; (b).Consumption yields of oxalic acid. Process parameters: $[\mathrm{AMX}]_{\mathrm{o}}=100 \mathrm{mg} \cdot \mathrm{L}^{-1},\left[\mathrm{Fe}^{3+}\right]_{\mathrm{o}}=0.35 \mathrm{mM}$ and $[\mathrm{OX}]_{\mathrm{o}}=3.15 \mathrm{mM}$, mixed for $135 \mathrm{~min}$.

Fig.7 Schema of the different type, algorithm and function for the modeling and optimization of the ANN.

Fig.8 The ANN optimized structure.

Fig.9 Comparison of the experimental results with those calculated via neural network modeling for outputs 1 (\% AMX) and 2 (\%TOC). (a). Comparison of the experimental results with those calculated via neural network modeling for outputs 1 (\% AMX). (b). Comparison of the experimental results with those calculated via neural network modeling for outputs 2 (\% AMX)

Fig.10 Effect of inorganic ions $\left(-\mathrm{O}_{4}{ }^{2-},-\mathrm{Cl}^{-},-\mathrm{HCO}_{3}^{-}\right)$on the degradation of AMX ( AMX), Process parameters: $[\mathrm{AMX}]_{\mathrm{o}}=100 \mathrm{mg} \cdot \mathrm{L}^{-1},\left[\mathrm{Fe}^{3+}\right]_{\mathrm{o}}=0.35 \mathrm{mM},[\mathrm{OX}]_{\mathrm{o}}=3.15 \mathrm{mM}$ and initial $\mathrm{pH}$ unadjusted, mixed for $135 \mathrm{~min}$. 
Fig.1

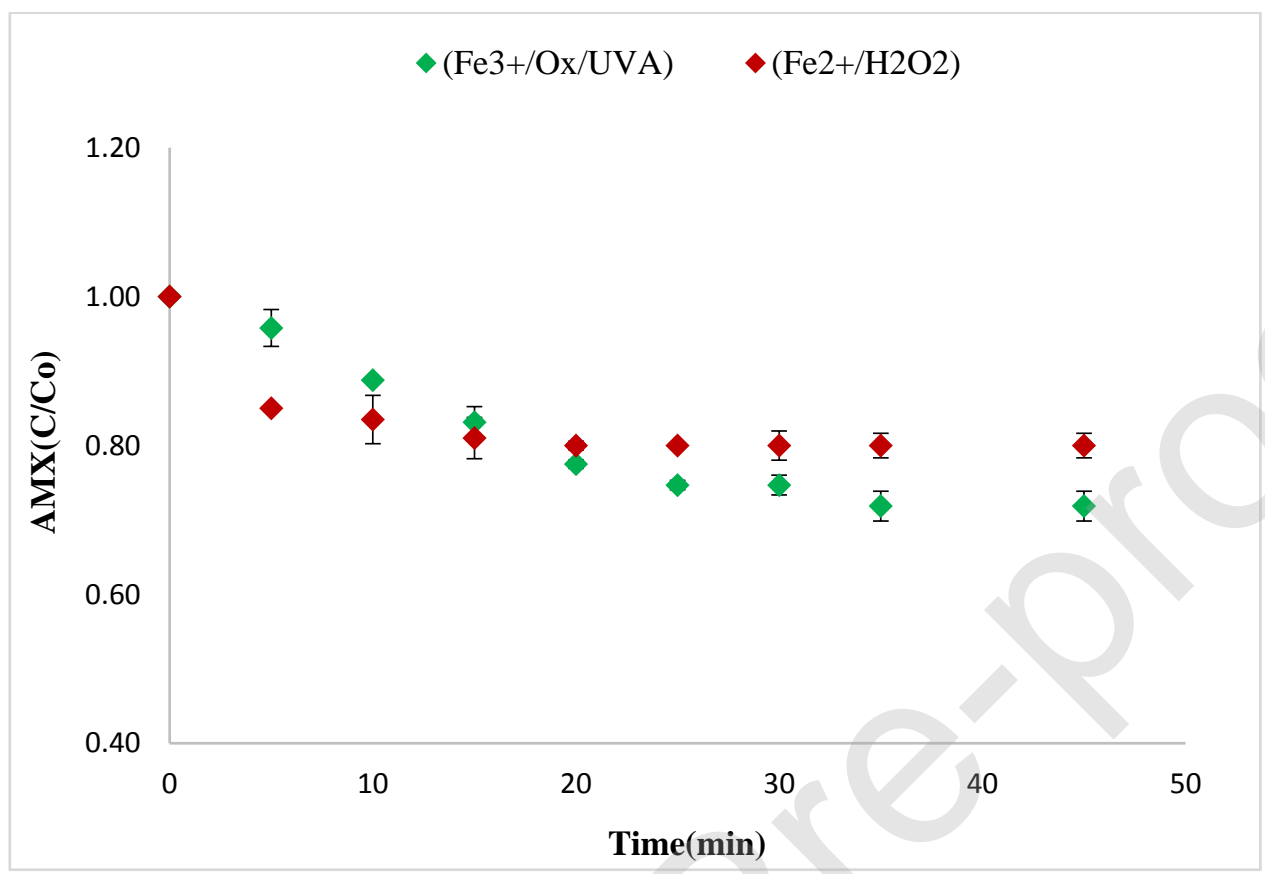


Fig.2
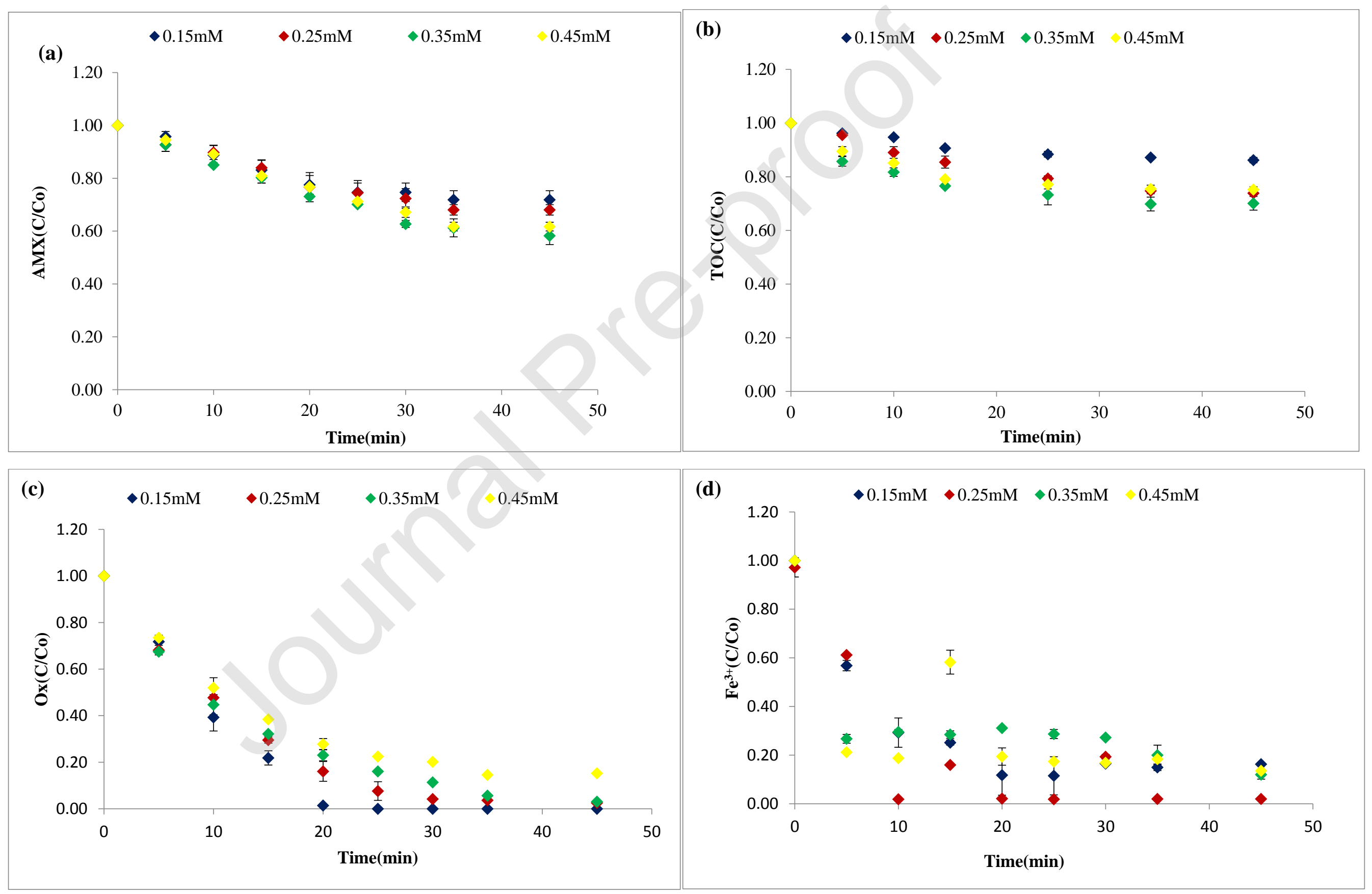
Fig.3

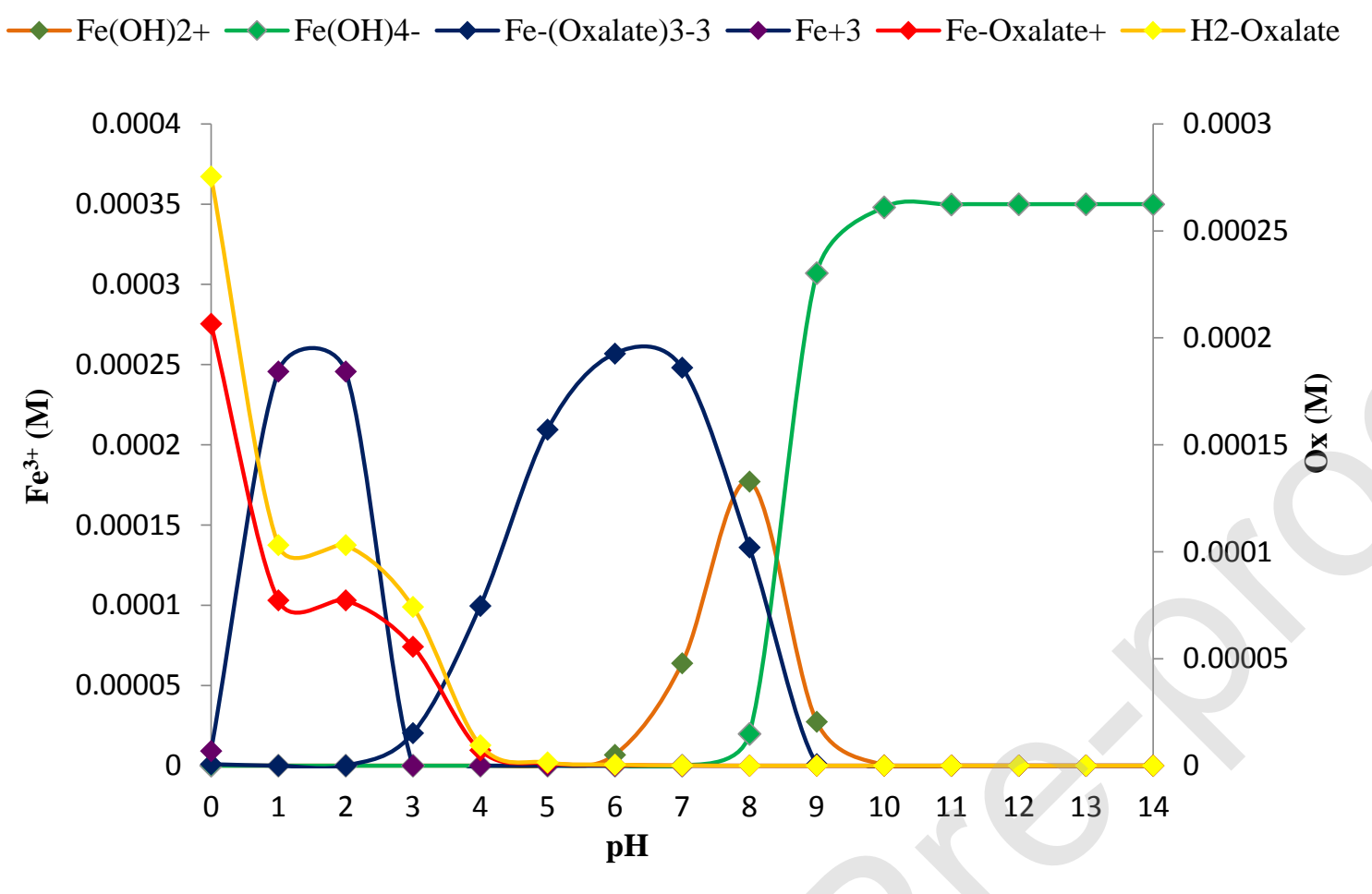




\section{Fig.4}

Journal Pre-proof
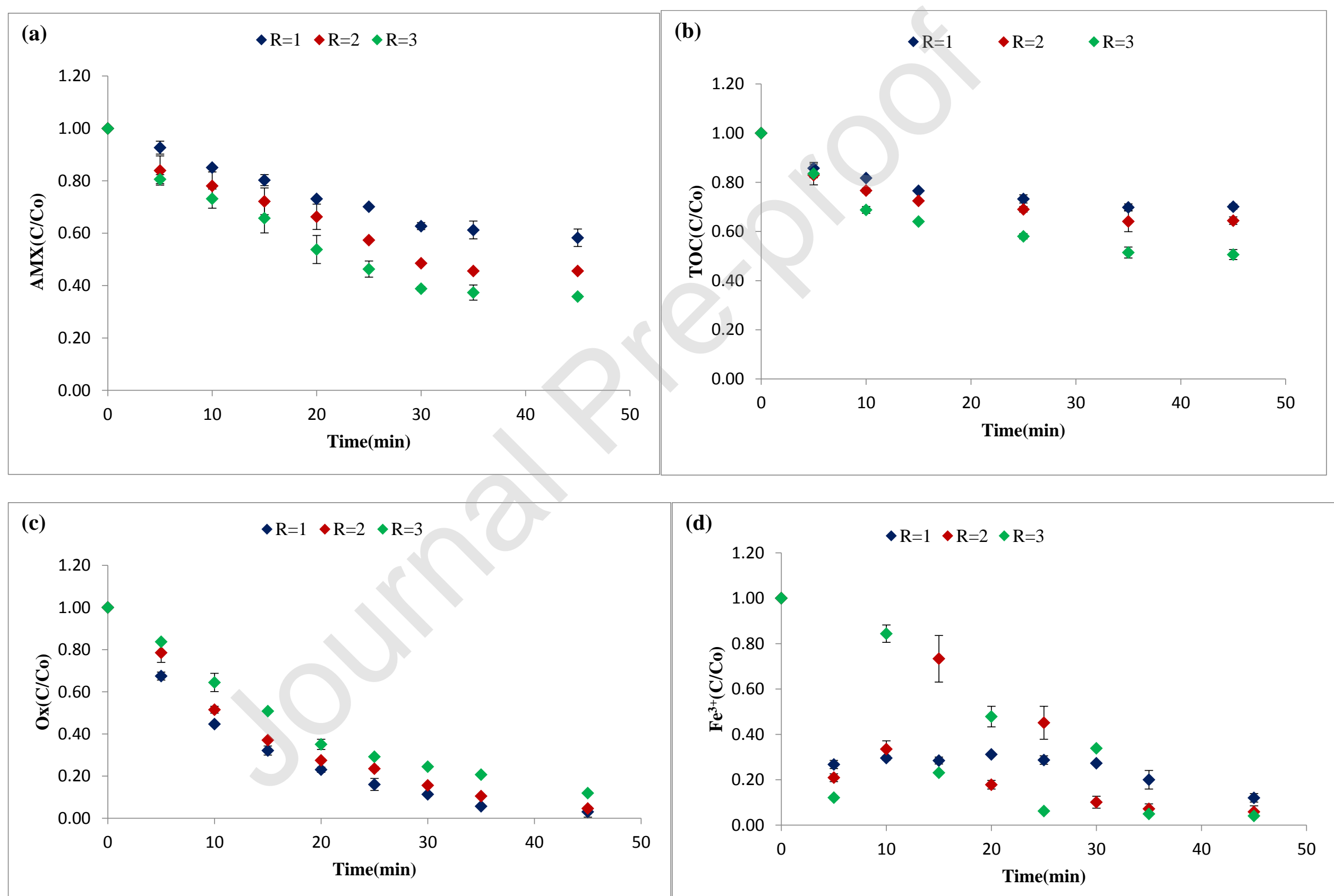


\section{Fig.5}
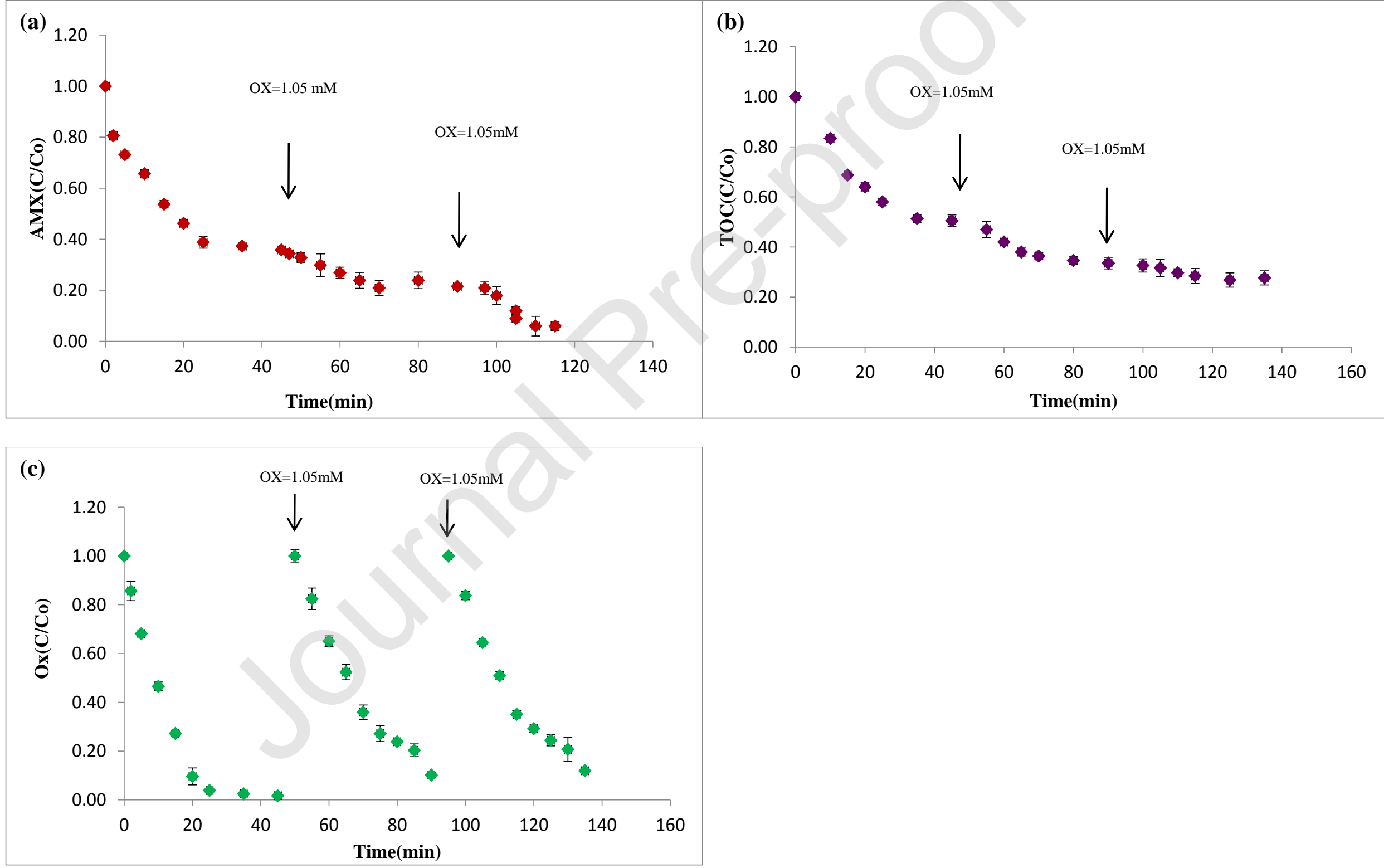

Fig.6 


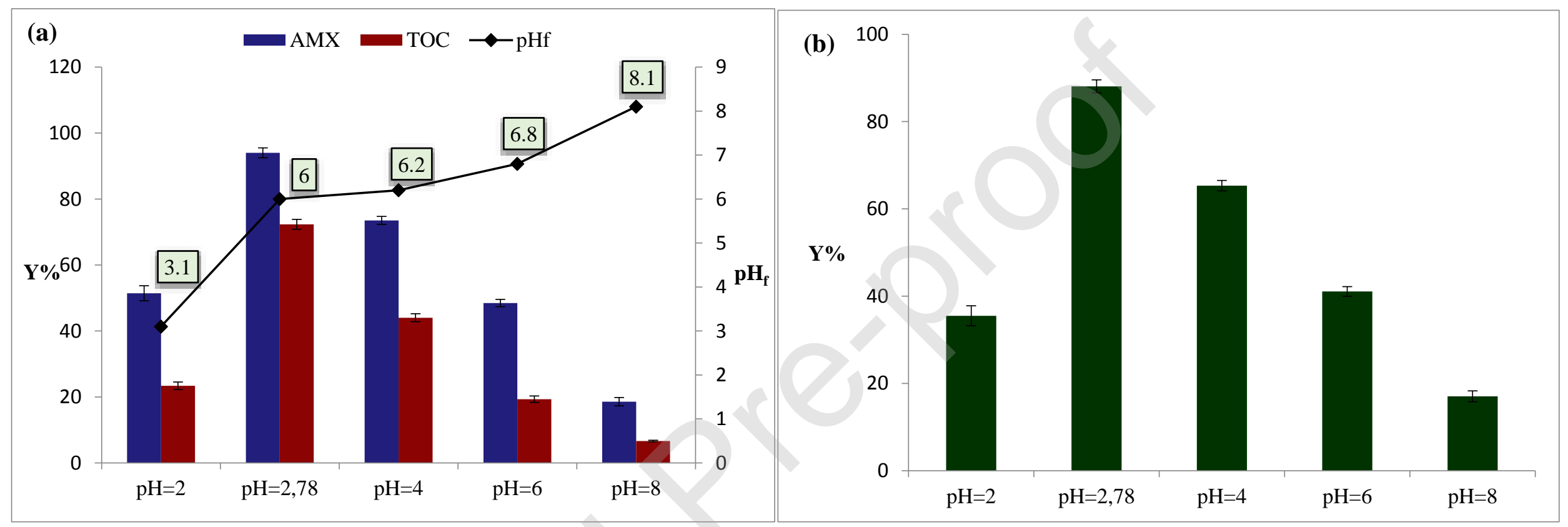

Fig.7 


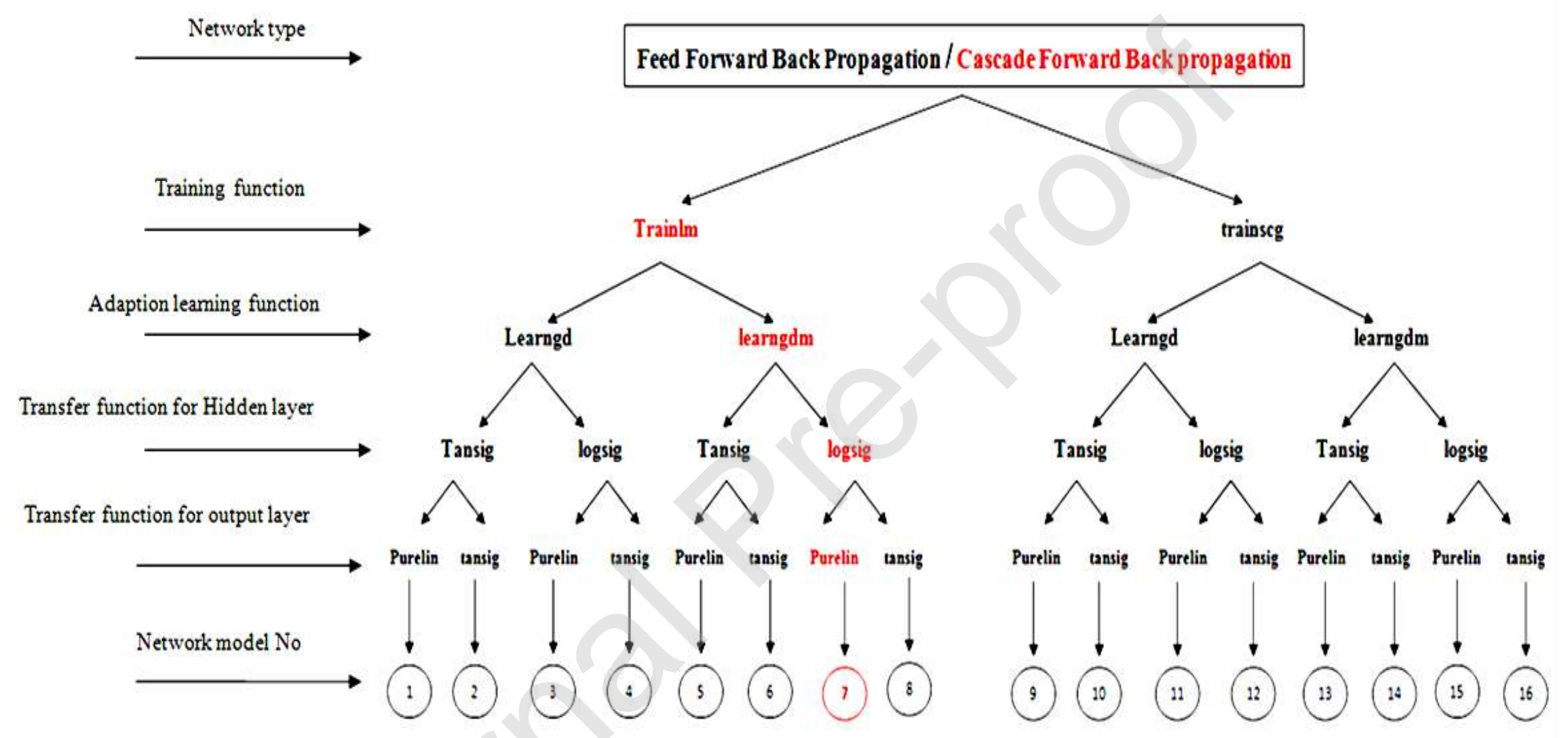

Fig.8 


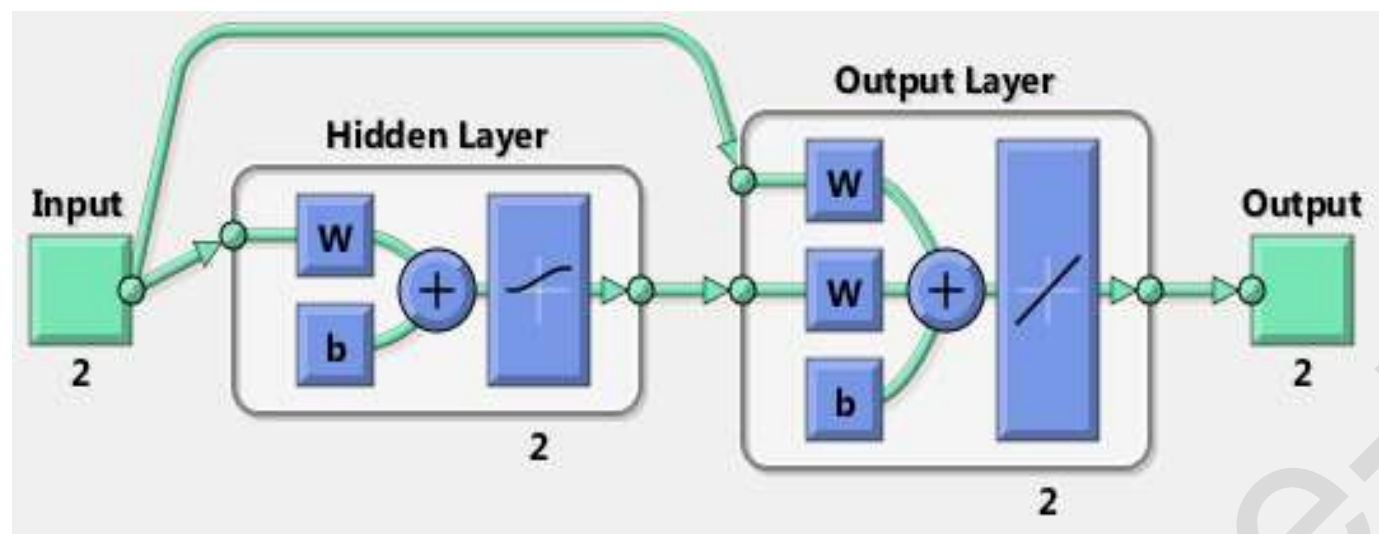




\section{Fig.9}

(a)

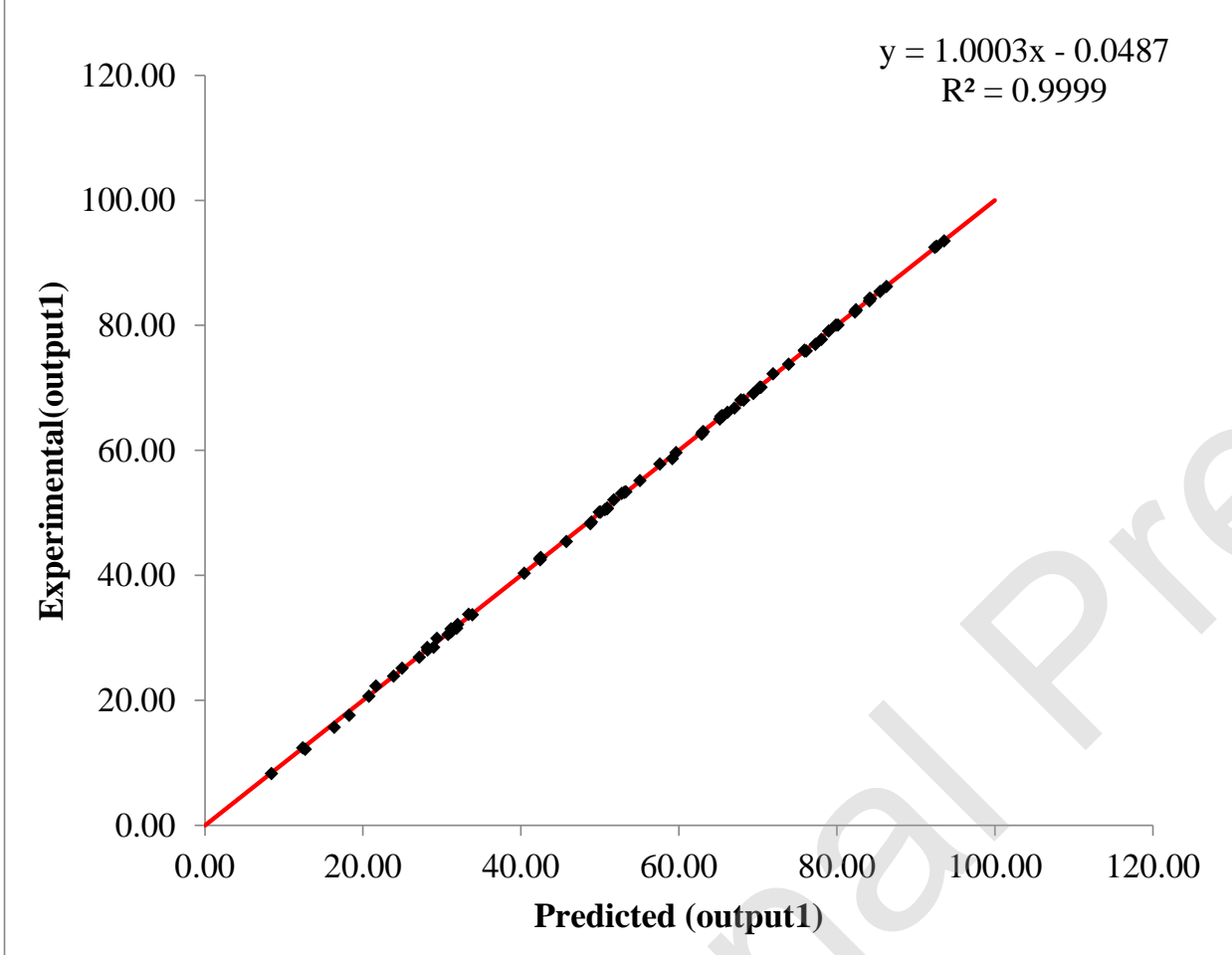

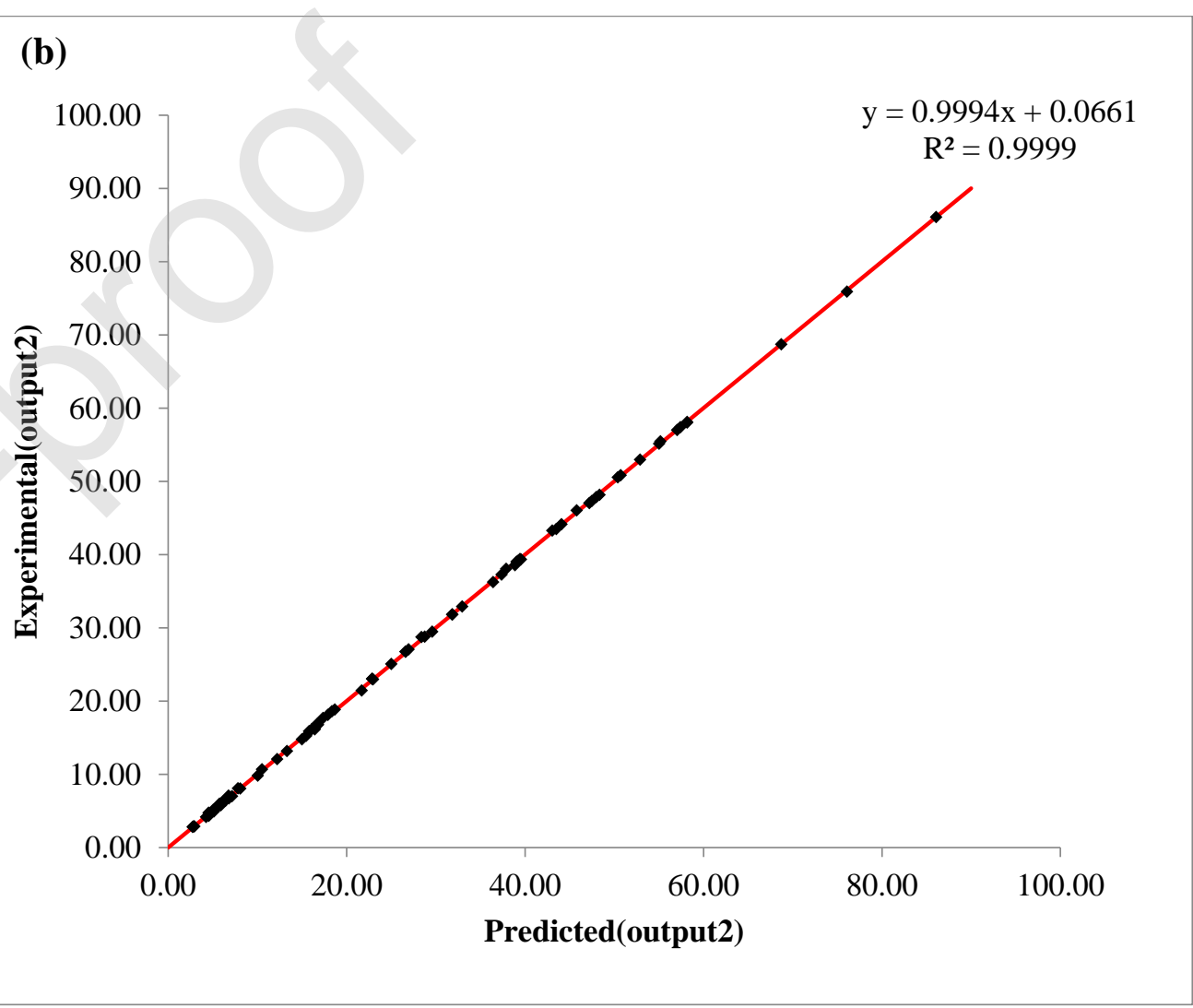


Fig.10

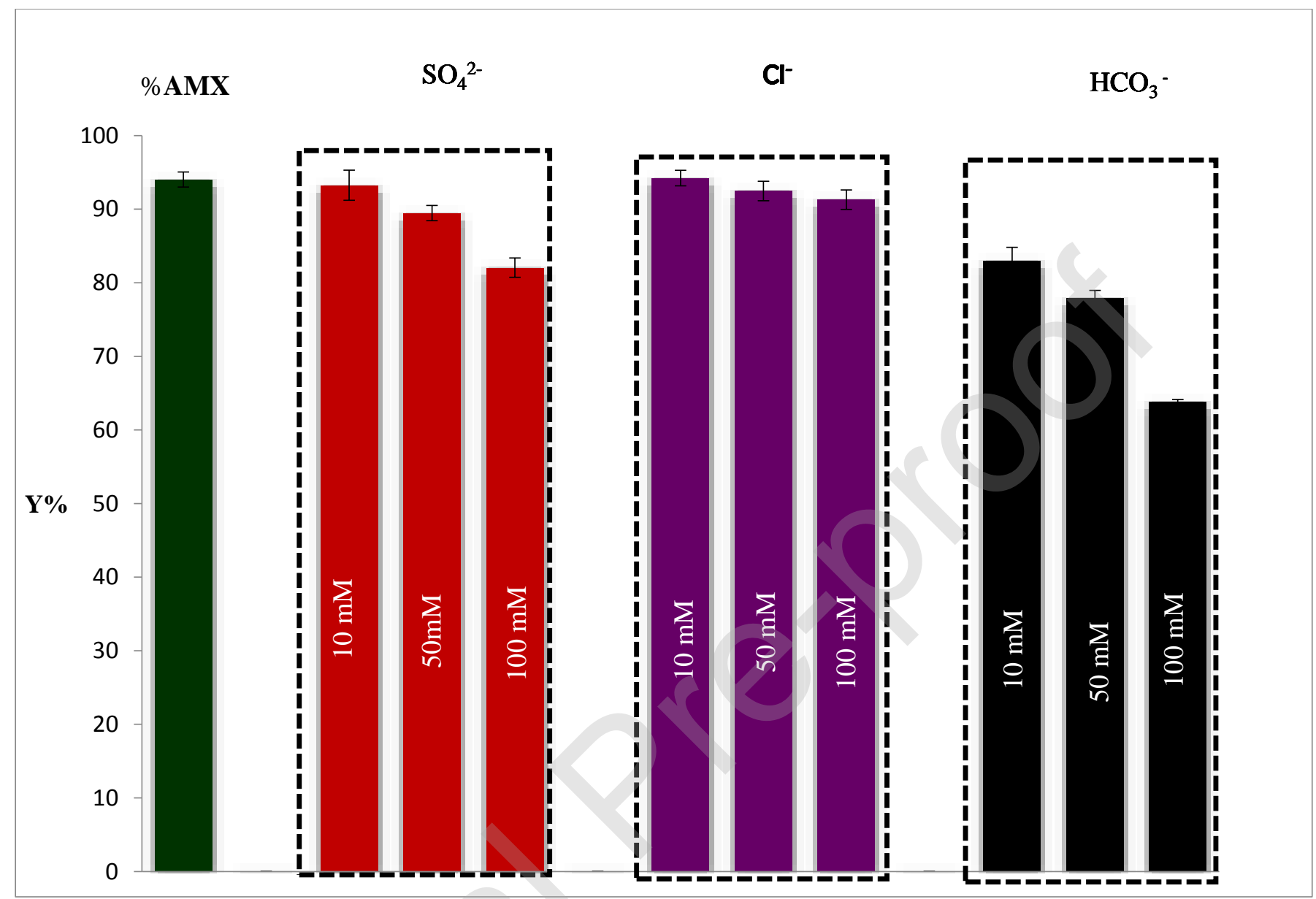


Table.1 The MSE of the ANN Models for both types of networks.

\begin{tabular}{|l|l|l|l|l|}
\cline { 2 - 5 } \multicolumn{2}{l|}{} & \multicolumn{2}{l|}{ Feed Forward Back Propagation } & \multicolumn{2}{l|}{$\begin{array}{l}\text { Cascade Forward Back } \\
\text { propagation }\end{array}$} \\
\hline $\begin{array}{l}\text { Numbre of } \\
\text { neurons }\end{array}$ & output 1([AMX]) & output 2 ([COT]) & output 1([AMX]) & output 2 ([COT]) \\
\hline 1 & 0.00014522 & $1.65143 \mathrm{E}-05$ & $1.56926 \mathrm{E}-05$ & $1.28163 \mathrm{E}-05$ \\
\hline 2 & 0.000599189 & 0.000647383 & 0.000102425 & 0.000158567 \\
\hline 3 & $1.52171 \mathrm{E}-05$ & $2.73573 \mathrm{E}-05$ & 0.001899822 & 0.001961148 \\
\hline 4 & 0.02826941 & 0.086593115 & 0.030507007 & 0.086824817 \\
\hline 5 & $8.47637 \mathrm{E}-05$ & 0.000139967 & 0.000260609 & $3.71719 \mathrm{E}-05$ \\
\hline 6 & $3.70679 \mathrm{E}-05$ & 0.000127639 & $2.97214 \mathrm{E}-05$ & $2.92166 \mathrm{E}-05$ \\
\hline 7 & $6.64265 \mathrm{E}-05$ & $7.03378 \mathrm{E}-05$ & $\mathbf{1 . 1 9 5 7 E - 0 5}$ & $\mathbf{1 . 1 9 4 8 2 E - 0 5}$ \\
\hline 8 & 0.028293735 & 0.086733243 & 0.028273919 & 0.08671381 \\
\hline 9 & 0.000469778 & 0.000227214 & 0.000278718 & 0.000129881 \\
\hline 10 & 0.001316821 & 0.001576089 & $8.0757 \mathrm{E}-05$ & 0.000439247 \\
\hline 11 & 0.0018198 & 0.000824118 & 0.000397543 & 0.000340885 \\
\hline 12 & 0.028380543 & 0.086706329 & 0.028325797 & 0.094981329 \\
\hline 13 & 0.000118855 & 0.000145659 & 0.001045723 & 0.001878532 \\
\hline 14 & 0.001199719 & 0.001188769 & 0.000376937 & 0.000865203 \\
\hline 15 & 0.001568241 & 0.002990617 & 0.000581513 & 0.000835322 \\
\hline 16 & 0.028626286 & 0.094980263 & 0.086789387 & 0.086789387 \\
\hline
\end{tabular}


Table.2 Effect of the number of hidden neurons on the ANN model performance for both outputs.

\begin{tabular}{|l|l|l|l|l|}
\cline { 2 - 5 } \multicolumn{2}{l|}{} & \multicolumn{2}{l}{ Output 1\%AMX) } & \multicolumn{2}{l}{ Output 2 (COT\%) } & \multicolumn{2}{l|}{} \\
\hline $\begin{array}{l}\text { Number of } \\
\text { neurons }\end{array}$ & MSE & $\mathbf{r}$ & MSE & \\
\hline 1 & 0.00036 & 0.99856 & 0.00109 & 0.99012 \\
\hline $\mathbf{2}$ & $\mathbf{1 . 1 5 4 3 4 \mathrm { E } - 0 5}$ & $\mathbf{0 . 9 9 9 9 5 4 1 4 8}$ & $\mathbf{1 . 1 2 1 6 2 E - 0 5}$ & $\mathbf{0 . 9 9 9 8 9}$ \\
\hline 3 & $1.18874 \mathrm{E}-05$ & 0.99995 & $1.14733 \mathrm{E}-05$ & 0.99989 \\
\hline 4 & $1.15743 \mathrm{E}-05$ & 0.99995 & $1.20176 \mathrm{E}-05$ & 0.99989 \\
\hline 5 & $1.39195 \mathrm{E}-05$ & 0.99994 & $1.13726 \mathrm{E}-05$ & 0.99989 \\
\hline 6 & $1.9235 \mathrm{E}-05$ & 0.99992 & $1.63017 \mathrm{E}-05$ & 0.99985 \\
\hline 7 & $1.23978 \mathrm{E}-05$ & 0.99995 & $1.21522 \mathrm{E}-05$ & 0.99989 \\
\hline & & 0.99992 & $1.45052 \mathrm{E}-05$ & 0.99987 \\
\hline
\end{tabular}


Table.3 Parameter values of the NSGA-II algorithm.

\begin{tabular}{|l|l|}
\hline Population size & 50 \\
\hline Number of generation & 100 \\
\hline Crossover rate & 0.8 \\
\hline Mutation rate & 0.01 \\
\hline
\end{tabular}


Table.4 Optimal conditions proposed by GA with their predicted and experimental values.

\begin{tabular}{|l|l|l|l|l|l|}
\cline { 3 - 6 } \multicolumn{2}{c}{} & \multicolumn{3}{l}{ Predicted } & \multicolumn{2}{l|}{ Experimental } \\
\hline $\mathbf{R}$ & $\mathbf{F e}^{3+}$ & {$[$ AMX] } & {$[\mathbf{C O T}]$} & {$[$ AMX] } & {$[$ COT] } \\
\hline 9.4 & 0.39 & 94.061 & 73.78 & 93.78 & 73.64 \\
\hline 9.5 & 0.39 & 94.04 & 73.87 & 94.71 & 73.45 \\
\hline 9.7 & 0.39 & 93.98 & 73.08 & 93.01 & 73.15 \\
\hline 9.8 & 0.39 & 93.93 & 72.86 & 93.99 & 73.27 \\
\hline 9.9 & 0.39 & 93.86 & 73.60 & 93.12 & 74.21 \\
\hline 10 & 0.39 & 93.78 & 74.29 & 94.68 & 74.88 \\
\hline 10.1 & 0.39 & 93.65 & 75.21 & 94.17 & 74.91 \\
\hline 10.2 & 0.39 & 93.51 & 75.10 & 94.58 & 75.9 \\
\hline
\end{tabular}

